\title{
Perhitungan Biaya Pemasukan Dalam Menetapkan Harga Jual Dan Jasa Pada PT Trimitra Solusindo
}

\author{
Hendriyati Haryani ${ }^{1}$, Mutiara Angela ${ }^{2}$, Nurmaida Azizah Al Wahni \\ ${ }^{1}$ Program Studi Akuntansi Universitas Raharja, ${ }^{2,3}$ Program Studi Sistem Informasi Universitas \\ Raharja \\ Email : hendriyati@ raharja.info, ${ }^{* 2}$ mutiara.angela@ raharja.info,nurmaida@ raharja.info
}

\begin{abstract}
Abstrak
Riset ini bertujuan guna menganalisis perhitungan anggaran pesanan dalam menetapkan harga jual pada PT Trimitra Solusindo. Analisis penentuan harga pokok penjualan dengan pendekatan metode Full Costing. Harga pokok pesanan lewat metode Full Costing pada PT Trimitra Solusindo pada tahun 2014 yakni sebesar Rp 91.910.000,- sedangkan harga pokok penjualannya yakni sebesar Rp 175.000.000,-. Pada Tahun 2015 harga pokok produksi lewat metode Full Costing PT Trimitra Solusindo alami kenaikan menjadi sebesar Rp 142.805.000,sedangkan harga pokok penjualannya yakni sebesar Rp 273.000.000,-. Kenaikan harga pokok produksi serta harga pokok penjualan ini diakibatkan karna jumlah produksi rosban pada PT Trimitra Solusindo hadapi kenaikan sehingga seluruhnya anggaran yang terdapat juga alami kenaikan. Harga jual rosban yang mesti diresmikan oleh PT Trimitra Solusindo guna memperoleh laba sesuai dengan targetnya pada tahun 2014 yakni sebesar Rp 3.500.000 perunitnya sedangkan pada tahun 2015 harga jual rosban yang mesti diresmikan oleh PT Trimitra Solusindo guna memperoleh laba sesuai dengan targetnya pada yakni sebesar Rp 4.200.000 perunitnya.
\end{abstract}

\section{Abstract}

This research aims to analyze the calculation of the order budget in setting the selling price at PT Trimitra Solusindo. Analysis of determining the cost of goods sold with the Full Costing method approach. The cost of goods ordered through the Full Costing method at PT Trimitra Solusindo in 2014 was Rp. 91.910.000,- while the cost of goods sold was Rp. 175.000.000,-. In 2015 the cost of production through the Full Costing method of PT Trimitra Solusindo experienced an increase to Rp. 142.805.000,- while the cost of goods sold was Rp. 273.000.000,-. The increase in the cost of production and the cost of goods sold was due to the increase in the number of Rosban production at PT Trimitra Solusindo, so that the entire existing budget also experienced an increase. The selling price of rosban which must be inaugurated by PT Trimitra Solusindo in order to obtain a profit in accordance with its target in 2014 is Rp. 3.500 .000 per unit, while in 2015 the selling price of rosban which must be inaugurated by PT Trimitra Solusindo in order to earn a profit is in accordance with its target, namely: IDR 4,200,000 per unit.

\section{Pendahuluan}

Dalam pengembangan bisnis yang lebih luas, itu akan mengarah pada lebih banyak Persaingan sengit di dalam dan bahkan di luar daerah. Persaingan yang ketat membuat banyak pengusaha mencari cara untuk menjaga kelangsungan usaha, oleh karena itu perusahaan dituntut untuk lebih inovatif, kreatif dan strategi yang tepat dan bijaksana agar dapat bertahan dalam persaingan terutama di masa pandemi. Ketika setiap perusahaan menjalankan bisnis, baik yang bergerak di bidang perdagangan, industri atau jasa, pasti memiliki tujuan tertentu, yaitu 
menggunakan sumber daya yang tersedia seefisien mungkin untuk memaksimalkan keuntungan. Secara garis besar, suatu perusahaan selalu berharap untuk berpedoman pada prinsip-prinsip ekonomi dalam menjalankan usahanya, yaitu berusaha untuk mendapatkan keuntungan yang sebesar-besarnya dengan biaya yang minimum. Salah satu upaya manajemen untuk mencapai tujuan perusahaan adalah melalui penggunaan strategi modal kerja. Penggunaan modal kerja sangat penting bagi strategi bersaing perusahaan. Dalam suatu perusahaan, laba yang diharapkan seringkali tidak tercapai sesuai dengan target, dan standar yang digunakan untuk mengukur berhasil tidaknya suatu manajemen perusahaan adalah laba yang diperoleh, karena laba biasanya menjadi tujuan utama perusahaan. Jika dalam periode akuntansi yang sama, jumlah pendapatan lebih besar dari biaya yang dikeluarkan, maka diperoleh laba. Untuk membantu perusahaan dalam menggunakan modal kerja, manajemen dapat menggunakan alat analisis yang disebut analisis laba kotor. Untuk merencanakan pencapaian laba yang diharapkan perusahaan, maka perusahaan perlu membuat anggaran. Agar anggaran benar-benar efektif, sistem anggaran yang baik harus mencakup perencanaan.

\section{Metode Penelitian}

Dalam penelitian ini jenis dan sumber data yang digunakan adalah data kuantitatif dan data kualitatif. Menurut sumbernya, data penelitian ini dapat dibagi menjadi dua kategori, yaitu data mentah dan data bekas. Metode pengumpulan data yang digunakan adalah observasi.

\section{Hasil Dan Pembahasan}

Menganalisis dan mendiskusikan semua data yang terkumpul untuk penelitian di PT. Trimitra Solusindo untuk menarik kesimpulan dari penelitian tersebut. Untuk lebih jelasnya akan dilakukan analisis data sebagai berikut.

1. Biaya Penjualan

Karena persediaan bahan baku yang diolah menjadi produk jadi, perhitungan harga pokok penjualan oleh perusahaan manufaktur menjadi sedikit rumit. Dalam proses pengolahan bahan baku menjadi produk jadi, akan timbul biaya-biaya lain, antara lain: biaya produksi tidak langsung dan biaya tenaga kerja.Penjualan terlebih dahulu menghitung biaya produksi dari inverter. akuntansi biaya penuh.

Metode biaya penuh adalah metode penentuan biaya produksi dimana semua unsur biaya produksi diperhitungkan dalam biaya produksi yang meliputi biaya bahan baku, biaya tenaga kerja langsung, dan biaya tidak langsung pabrik yang bersifat variabel atau tetap.

Harga Pokok Penjualan HPP adalah istilah yang digunakan dalam akuntansi keuangan dan perpajakan untuk menggambarkan biaya langsung barang yang diproduksi dan dijual dalam kegiatan bisnis. Ini termasuk biaya bahan baku, tenaga kerja langsung, biaya overhead, biaya pemasaran dan penyusutan aktiva. HPP muncul pada laporan laba rugi sebagai komponen utama dari biaya operasi atau biasa juga disebut sebagai biaya penjualan.

\section{Harga Pokok Pesanan Melalui Metode Full Costing Pt Trimitra Solusindo Priode Tahun 2014-2015}




\begin{tabular}{|c|l|c|c|}
\hline \multirow{2}{*}{ No } & \multirow{2}{*}{ Keterangan } & \multicolumn{2}{|c|}{ Tahun } \\
\cline { 3 - 4 } & & 2014 & 2015 \\
\hline 1 & Pembelian Bahan Baku & $\mathrm{Rp} 50.560 .000$ & $\mathrm{Rp} 90.150 .000$ \\
\hline 2 & Upah tenaga kerja langsung & $\mathrm{Rp} 20.800 .000$ & $\mathrm{Rp} 26.880 .000$ \\
\hline 3 & Biaya overhead produksi & $\mathrm{Rp} 4.300 .000$ & $\mathrm{Rp} 7.500 .000$ \\
\hline 4 & Biaya tetap & $\mathrm{Rp} 16.250 .000$ & $\mathrm{Rp} 18.275 .000$ \\
\hline \multicolumn{2}{|}{$\quad$ Harga pokok } & $\mathrm{Rp} 91.910 .000$ & $\mathrm{Rp} 142.805 .000$ \\
\hline
\end{tabular}

Dari tabel di atas dapat diketahui bahwa nilai untuk pembelian bahan baku pada $\mathrm{Pt}$ Trimitra Solusindo pada tahun 2014 adalah sebesar Rp. 50.560.000, upah tenaga kerja langsung Rp. 20.800.000, biaya overhead produksi Rp. 4.300 .000 dan biaya tetap Rp. 16.250.000. Pada tahun 2015 pembelian bahan baku melalui metode Full Costing pada Pt Trimitra Solusindo adalah sebesar Rp. 90.150.000, upah tenaga kerja langsung $\mathrm{Rp}$. 26.880.000, biaya cost produksi Rp. 7.500.000 dan biaya tetap Rp. 18.275.000.

Penentuan Harga Jual Inverter Pada dasarnya penetapan harga jual yang baik dilakukan oleh perusahaan adalah dengan cara melihat biaya yang telah dikeluarkan untuk memproduksi suatu produk, jika perusahaan telah melakukan hal yang yang baik dilakukan oleh perusahaan adalah dengan cara menang wajar bagi para pemilik perusahaan serta mempertahankan dan mengembangkan perusahaan. Tidak hanya itu serta wajib didetetapkan berapa target keuntungan yang mau didapatkan oleh industri dalam produk yang dihasilkan.

Adapun target keuntungan yang ingin didapatkan oleh Pt Trimitra Solusindo guna tiap produk Inverter yaitu sebesar $20 \%$ dari bayaran pembuatan satu Inverter. Pada riset ini periset hendak menetapkan harga jual produk dengan pendekatan tata cara penentuan harga pokok produksi ialah dengan tata cara Full Costing. Penetapan Harga Jual dengan pendekatan harga pokok penciptaan Full Costing Penetapan Harga Jual dengan pendekatan harga pokok pembuatan Full Costing bisa dilihat pada tabel berikut:

\section{Penjualan Pesanan Pada Pt Trimitra Solusindo Periode Tahun 2014-2015}

\begin{tabular}{|c|c|c|c|}
\hline Tahun & Jumlah Penjualan (Unit) & Harga Jual & Total Penjualan \\
\hline 2014 & 50 Unit & $\mathrm{Rp} 3.500 .000$ & $\mathrm{Rp} 175.000 .000$ \\
\hline 2015 & 65 Unit & $\mathrm{Rp} 4.200 .000$ & $\mathrm{Rp} 273.000 .000$ \\
\hline
\end{tabular}

Berdasarkan data di atas maka dapat diketahui penjualan pesanan pada Pt Trimitra Solusindo dari tahun 2014 - 2015 adalah sebagai berikut :

Pada tahun 2014 jumlah penjualan adalah 50 unit dengan harga jual 1 unit adalah Rp. 3.500.000 sehingga total penjualan pada tahun 2014 adalah senilai Rp175.000.000 dan pada tahun 2015 jumlah penjualan adalah 65 unit dengan harga 1 unit adalah Rp4.200.000 sehingga total penjualan pada tahun 2015 adalah senilai Rp273.000.000

Laba Usaha = Harga Jual - Harga Pokok Penjualan / Harga Jual x $100 \%$

$=\mathrm{Rp} 175.000 .000-\mathrm{Rp} 91.910 .000 / \mathrm{Rp} 175.000 .000 \times 100 \%$

$=\operatorname{Rp} 83.090 .000 / \mathrm{Rp} 175.000 .000 \times 100 \%$

$=47,48 \%$

Laba Usaha = Harga Jual - Harga Pokok Penjualan / Harga Jual x $100 \%$

$=\mathrm{Rp} 273.000 .000-\mathrm{Rp} 142.805 .000 / \mathrm{Rp} 273.000 .000 \times 100 \%$

$=\operatorname{Rp} 130.195 .000 / \operatorname{Rp} 273.000 .000 \times 100 \%$

$=47,69 \%$

Berdasarkan hasil perhitungan laba usaha diatas maka dapat dilihat pada : 


\section{Penjualan Pesanan Pada PT Trimitra Solusindo Tahun 2014-2015}

\begin{tabular}{|c|c|}
\hline Tahun & Laba Usaha \\
\hline 2014 & $47,48 \%$ \\
\hline 2015 & $47,69 \%$ \\
\hline
\end{tabular}

\section{Penjualan Pesanan Pada PT Trimitra Solusindo Tahun 2014-2015}

\begin{tabular}{|c|cc|cc|}
\hline Keterangan & \multicolumn{2}{|c|}{2014} & \multicolumn{2}{c|}{2015} \\
\hline Penjualan & $\mathrm{Rp}$ & 175.000 .000 & $\mathrm{Rp}$ & 273.000 .000 \\
\hline HPP & $\mathrm{Rp}$ & 91.910 .000 & $\mathrm{Rp}$ & 142.805 .000 \\
\hline Laba Bersih Usaha & $\mathrm{Rp}$ & 83.090 .000 & $\mathrm{Rp}$ & 130.195 .000 \\
\hline \% Laba Bersih & \multicolumn{2}{|c|}{$47,48 \%$} & \multicolumn{2}{c|}{$47,69 \%$} \\
\hline
\end{tabular}

\section{Kesimpulan}

Adapun kesimpulan dari penelitian ini yaitu:

1. Harga pokok pesanan melalui metode Full Costing pada PT Trimitra Solusindo pada tahun 2014 yaitu sebesar Rp 91. 910. 000,- sedangkan harga pokok penjualannya adalah sebesar Rp 175. 000. 000,-. Pada Tahun 2015 harga pokok pembuatan lewat metode Full Costing PT Trimitra Solusindo alami peningkatan jadi sebesar Rp 142. 805. 000,sedangkan harga pokok penjualannya yaitu sebesar Rp 273. 000. 000,-. Peningkatan harga pokok pembuatan dan harga pokok penjualan ini dikarenakan karna jumlah pembuatan Inverter PT Trimitra Solusindo alami peningkatan sehingga seluruhnya pengeluaran yang terselip serta alami peningkatan.

2. Harga jual Inverter yang harus ditetapkan oleh PT Trimitra Solusindo guna mendapatkan laba sesuai dengan targetnya pada tahun 2014 yaitu sebesar Rp 3. 500. 000 perunitnya sedangka pada tahun 2015 harga jual Inverter yang mesti ditetapkan oleh PT Trimitra Solusindo buat mendapatkan laba sesuai dengan targetnya pada yaitu sebesar Rp 4. 200. 000 perunitnya.

\section{Saran}

Pada PT Trimitra Solusindo sebaiknya sering menetapkan harga jual produk Inverter dengan memakai pendekatan Metode Full Costing agar mendapatkan gambaran dalam menentukan harga jual produknya tersebut guna memperoleh laba yang telah ditargetkan sebelumnya. dalam hal ini pemasaran sangat berperan penting untuk kelangsungan penjualan di PT Trimitra Solusindo.

\section{Daftar Pusaka}

1. Arianta, K. D., Atmadja, A. T., Se, A., \& Sulindawati, N. L. G. E. (2017). Analisis Perhitungan Biaya Produksi Pada Usaha Mikro, Kecil Dan Menengah (Umkm) Jajanan Cita Rasa Khas Bali (Studi Kasus Pada Ud. Sari Artha Kue Di Desa Banjar, Kecamatan Banjar). Jimat (Jurnal Ilmiah Mahasiswa Akuntansi) Undiksha, 8(2). 
2. Kurniawan, D. (2012). Penerapan Sistem Akuntansi Biaya Untuk Meningkatkan Tingkat Akurasi Biaya Produksi (Studi Praktik Kerja Pada Pt Hamparan Plastindo Raya). Jurnal Ilmiah Mahasiswa Akuntansi, 1(1), 16-20.

3. Worotitjan, C. R. F., \& Morassa, J. (2016). Analisis Perhitungan Biaya Produksi Pada Pt. Manado Nusantara Informasi (Koran Sindo). Jurnal Emba: Jurnal Riset Ekonomi, Manajemen, Bisnis Dan Akuntansi, 4(1).

4. Jannah, M. (2018). Analisis Pengaruh Biaya Produksi Dan Tingkat Penjualan Terhadap Laba Kotor. Banque Syar'i: Jurnal Llmiah Perbankan Syariah, 4(1), 87-112.

5. Anggraeni, I., Priatna, H., \& Madaniah, D. (2020). Pengaruh Biaya Bahan Baku Dan Biaya Tenaga Kerja Terhadap Volume Produksi Pada Cv Ismaya Citra Utama. Akurat| Jurnal Ilmiah Akuntansi Fe Unibba, 11(2), 22-32.

6. Wokas, H., Saerang, D. P. E., \& Taawoeda, G. (2014). Penerapan Akuntansi Biaya Bahan Baku Dalam Proses Produksi Pada Pt. Putra Karangetang Minahasa Selatan. Jurnal Riset Ekonomi, Manajemen, Bisnis Dan Akuntansi, 2(3), 2334.

7. Rahmawati, R., \& Surya, F. (2016). Analisis Perhitungan Biaya Pesanan Dalam Menetapkan Harga Jual Pada Usaha Las Palandan Di Desa Palandan Kecamatan Baebunta Kabupaten Luwu Utara. Jurnal Akuntansi Stie Muhammadiyah Palopo, 1(2).

8. Sari, R. N. (2017). Perlakuan Akuntansi Biaya Pengembangan Sumber Daya Manusia Pada Perusahaan Daerah Air Minum Kota Samarinda. Akuntabel, 13(1), 32-47.

9. Sumarsih, S., \& Mukminan, M. (2016). Pengembangan Multimedia Akuntansi Biaya Metode Harga Pokok Pesanan Bagi Mahasiswa Jurusan Pendidikan Akuntansi Uny. Jurnal Inovasi Teknologi Pendidikan, 3(1), 92-105.

10. Baru Harahap, S. E., Ak, M., Kom, T. S., \& Si, M. (2020). Akuntansi Biaya. Cv Batam Publisher. 